\title{
Learning Selves and Citizenship: Gender and Youth Transitions
}

\author{
TOM HALL* and AMANDA COFFEY** \\ * School of Social Sciences, Cardiff University, Glamorgan Building, King Edward VII \\ Avenue, Cardiff CF10 3WT \\ email: HallTA@cardiff.ac.uk \\ ** School of Social Sciences, Cardiff University, Glamorgan Building, King Edward VII \\ Avenue, Cardiff CF10 3WT \\ email: Coffey@cf.ac.uk.
}

\begin{abstract}
Discourses of citizenship have increasingly featured in social policies aimed at young people, particularly in relation to the promotion and crafting of 'active citizens'. The inclusion of citizenship education in school curricula, the Learning and Skills development agency post16 citizenship development programme, and the recent Green Paper Youth Matters, all speak of instilling in young people the rights and responsibilities that come with citizenship. In this article we draw on empirical work on youth transitions to explore the ways in which citizenship is learnt and lived by young people themselves. The article draws on some of the models of citizenship identified by Lister et al. (2003) in their study on young people's perceptions of citizenship, particularly considering them in relation to the gendered experiences and realities of youth transitions to adulthoods.
\end{abstract}

\section{Introduction}

Citizenship is currently high on social and political agendas in the UK, in relation to a range of issues and social groups. Young people - 'citizens in the making' have featured prominently in these agendas. Educating for citizenship is an explicit part of government policy; more generally, the supposedly disaffected and disadvantaged young have also provided the sub-text to much of the public anxiety about social exclusion and the 'underclass' in Britain (MacDonald, 1997b: 18). A recent example, and manifestation, of this concern with young people and citizenship is the Green Paper Youth Matters published by the Department for Education and Skills in July 2005 (DfES, 2005). Building directly on the recommendations of the Russell Commission (Russell, 2005), Youth Matters outlines a strategy for 'providing opportunities, challenge and support for young people' (DfES, 2005: 5). The Green Paper proposals speak directly to component discourses of citizenship: empowerment - through providing more 'things to do and places to go' (p. 5); making a contribution - through 'peer mentoring, sustained civic service and a stronger culture of volunteering' (p. 7); information 
and guidance - to support choices that have an effect on 'young people's future wellbeing and on their ability to contribute to wider society and the economy' (p. 7); and integrated service provision - particularly to support those 'young people at risk of poor outcomes' (p. 9), where poor outcomes include teenage pregnancy, drugs and youth crime, and exclusion from education, training or work. Young people and citizenship were in the headlines earlier in 2005 with the announcement by the (then) Home Secretary, Charles Clarke, of proposed citizenship ceremonies for eighteen-year-olds. This proposal was met with a mixed but mostly lukewarm response at the level of party political and media comment, and one wonders what the first cohort of actual initiands will make of it - and what it is that eighteen-year-olds make of citizenship itself for that matter.

Over the last fifteen years or so, the vocabulary of citizenship has made a more prominent entry into the empirical sociology of youth transitions - as a way in which to talk about, and make sense of, the movement into social majority and adult independence. This has been mirrored by the increasing calls to discourses of citizenship, in respect of young people, from government and from social science more generally. However we would contend that it has not done so as an emic term - one which young people themselves have been using and to which researchers have then paid attention. Rather, citizenship has been (and remains, we suspect) an etic vocabulary as far as most young people are concerned. Growing up and older, and what this means for who you are, to yourself and to others: these are issues of immediate importance to young people, and to sociologists of youth as well. But if 'citizenship' has helped us to understand something here, then it has done so as an exterior vocabulary, enabling an assessment of the extent to which young people's transitions - fragmented, plural, risk-laden, in the language of the times - might amount to a full and 'successful' move into social majority and membership as independent adults.

Citizenship, in the context of youth transitions, necessarily facilitates consideration of a composite status and identity - adult, self-reliant, empowered, engaged, enabled, included - that some may struggle to achieve, and has given sociologists and others a way of talking about that struggle. In this article we attempt to unravel some of the accomplishments and identities often bundled together under the heading 'citizenship' in relation to young people (and implicit in the consultation taking place on Youth Matters). In doing so, we give particular consideration to gender. The differentiations of identity to which gender refers are always, no matter what else, massively externally defined (Jenkins, 2004); nonetheless these are identities that young people make their own - make it their business to work at and talk about. Gender has a bearing on, and is a part of, what it means to grow up and older, in a way that is only too apparent to young people, The identity work involved here, like that related to citizenship itself, is far from easy (see Mac an Ghaill, 1994; Proweller, 1998; Weis and Fine, 2000; Jenkins, 2004). Nonetheless we all accomplish and carry over into our adult 'citizen' lives 
gendered identities, however particular or difficult our youth transitions might have been (Walkerdine et al., 2001). It is our suggestion here that gender, and the formation and articulation of gendered identities, complicates citizenship (and citizenship discourses), not least in the context of youth transitions. The article thus explores some of the everyday gendered manifestations of 'citizens in the making', drawing on our own observations of youth transitions, and in relation to Lister et al.'s (2003) study of young people's perceptions of citizenship.

The article is in two main sections. In the first of these, the conceptualisation of citizenship in relation to young people, youth transitions and gender is placed in theoretical and policy context. This sets the scene for the second section, in which we specifically consider gender and citizenship. Our comments in the second half of the article are informed by our own research on youth identities and transitions, and citizenship agendas, in the particular context of youth work settings. Overall, the article is intended as a contribution to contemporary debates on youth, adulthood and the 'making' of citizens (see France, 1996, 1998; Coles, 1995; DfES, 2005; Hall et al., 1998; Macdonald and Marsh, 2004; Fergusson, 2004), and to nuanced understandings of gendered identity work and young people's everyday performance of gender (see Butler, 1990; Walkerdine et al., 2001; Renold, 2005).

\section{Methodological note}

The empirical research we have undertaken, and on which we draw in the second half of this article, has been reported elsewhere (see Hall et al., 1998, 1999, 2000). It is our intention here to engage discursively with notions of gender and citizenship, not to report on research findings in any further detail. Nevertheless, this discursive engagement is informed by empirical observation and illustrated by data exemplars, and some detail of the wider project from which these are taken is appropriate. The project, a funded study of youth work and young people's transitions to adult citizenship, was organised through observational and fieldwork visits to a range of different youth work settings in south and west Wales conducted over a two-year period. ${ }^{1}$ Sites for the research were strategically sampled to provide for a diversity of social and economic contexts, organisational structures and approaches to the delivery of services, and included 'traditional' boys' and girls' clubs, evening drop-in projects, advice centres, youth council initiatives, and a range of residential and outdoor activities. The aim, in engaging with each of these settings, was to gain an understanding of how informal educative and leisure settings might shape and enable young people's identitywork in making the move to independence and social majority. By focusing on processes of learning-through-leisure, the research documented some of the practices through which young people negotiate transitions to adulthoods in spaces located between the formal contexts of education and training and the domestic contexts of the home and family. Intensive and sustained fieldwork 
contact as participant observers in each of the research sites provided the principal means of data collection, and data thus collected were recorded as fieldnotes; this ethnographic approach was augmented by qualitative interviews with both young people and youth workers. The original research did not have the formation and negotiation of gender identities as its prime focus, although inevitably the identity work, interactions and understandings we encountered daily in all these settings were shaped by, and expressive of, gender. It is this gendered aspect of transitions to citizenship, adulthood and majority that we are concerned with here.

\section{Conceptualising and enacting citizenship}

In contemporary public and policy debates and discourses that have ensued over citizenship, there has been remarkably little attention afforded to gender, although it is hard to see how citizenship can be anything but located within frameworks of gender, equity and social justice. Indeed, it is impossible to separate social identity and citizenship from gendered (and indeed racialised, localised and generational) contexts. Feminist theorists have consistently revealed the ways in which women have been systematically excluded from both the theory and practice of citizenship, as part of a wider feminist project of critiquing the citizenship ideals of equality and universality that have been traditionally articulated. As Lister (2003: 68) argues, 'the universalist cloak of the abstract, disembodied individual has been cast aside to reveal a definitely male citizen and a white, heterosexual one, non-disabled one at that'. Lister has posed the challenge of diversity and difference for citizenship, alongside presenting a convincing analysis of the ways in which women have always played key roles in key citizenship struggles (suffrage, for example). Lister's own intellectual project, of re-gendering understandings and realities of citizenship, is (of course) more than simply 'adding women' to existing debates and articulations of citizenship. Rather, she reconsiders the process of becoming citizens - recognising the ways in which gendered citizenship(s) are negotiated, (re)produced and articulated in order to understand the ways in which gender 'troubles' the theory and the practice of citizenship. We might think about this in relation to how citizenship is defined, and how young people, and the institutions in which young people find themselves, work though what it is to be a citizen.

\section{Citizenship(s) considered}

There is no universally agreed and timeless definition of citizenship (Chisholm, 1997: 2), and the question 'what is citizenship?' can be answered in different ways and on different levels. At its simplest, citizenship can be narrowly defined as referring to legal membership of a nation or political community: a status afforded an individual, whose relationship with the community will necessarily entail reciprocal rights and duties. This definition does not readily 
admit to differing degrees of citizenship or allow for an appreciation of qualitative differences in the lived experience of citizenship. Instead a person's citizenship their status as a citizen - appears as a matter of fact and indeed law. Such a narrow definition has the minimal advantage of clarity. If citizenship is no more (or less) than its legal definition allows for, at least we know what we are talking about. Working within such a narrow definition might make for a rather limited discussion, but this does not make it impossible to work with such a definition. One might, for example, accept the legal definition but aim nonetheless to look beyond this so as to contextualise what legal citizenship means in practice and how other factors interact with this formal status, hence aiming at defining and understanding a kind of differentiated universalism (Lister, 2003). This is the approach that Jones and Wallace (1992) adopt in their exploration of the extent to which external factors, principally economic inequalities, structure access to citizenship for young people.

It is also possible to define citizenship in much more generous and general terms than those of legal status and entitlement. This moves toward an understanding of citizenship as a normative ideal, incorporating the central notion of membership and evoking a host of other related themes: belonging, independence, responsibility and participation. In present-day political exhortations about the importance of 'good' citizenship, it is invariably this normative sense of citizenship that is being shaped and (re)defined, rather than the actual legal framework of citizenship status, rights and duties (Hall et al., 1998). The notion of 'active citizenship' is important here, conveying a contemporary enthusiasm for citizenship responsibilities and active participation (as against a rights-based language of citizenship). Notions of active citizenship inform, and find expression in, both the report of the Russell Commission, A National Framework for Youth Action and Engagement, and the subsequent government Green Paper Youth Matters.

Commensurate with the enthusiasm for active citizenship is the widespread agreement that citizenship - as a quality, capacity or set of skills and understandings - is something to be elicited from and/or instilled in young people. Following the Crick report of 1998 (published by the Qualifications and Curriculum Authority: QCA), which cited 'worrying levels of apathy, ignorance and cynicism about public life' (QCA, 1998: 8), citizenship education is now a compulsory aspect of schooling in England, and is similarly foreshadowed in the devolved administrations of the UK (see, for example, National Assembly for Wales, 2001). The Learning and Skills Development Agency have taken forward the post-16 citizenship agenda, with their development programme (including citizenship courses, youth councils, volunteering opportunities and local community projects). Recent youth work and similar initiatives with an active citizenship focus include the Prince's Trust Young Volunteer Scheme, the Community Service Volunteers Action Programmes, The Millennium Volunteers and the European Voluntary Service Schemes. Thus, across a spectrum of contemporary citizenship education, 
training and youth work developments, we see the adoption and development of an active citizenship - combining themes of obligation, engagement, responsibility, caring, competency and participation. This notion of an active citizenship has been criticised both for its implicit construction of other citizenships as 'passive' (see Hall et al., 1998) and for the conservativeness of its delineation of what counts as legitimate citizenship activity (see Cunningham and Lavalette, 2004).

The relationship between citizenship and social identity further complicates matters. Much of the contemporary political and policy enthusiasm for citizenship is for citizenship as an identity. We are all encouraged, young people in particular, to think of ourselves as citizens - through national government initiatives and events such as Citizens' Day. ${ }^{2}$ Yet the negotiatedness of the social identities we commonly live with and through stands in some contrast to the formal and asocial character of citizenship conventionally understood, making it rather too cumbersome for use in the everyday and personal complexities of social interaction. Active citizenship, of course, seeks to bring citizenship as identity to life, fitting it to the everyday life of individuals and communities, although it remains to be seen whether and how this can be achieved. In this context, then, we might want to draw on an understanding of 'lived citizenship' (Hall and Williamson, 1999: 2) to consider the ways in which young people's personal, social and cultural backgrounds structure their experience of, and the meanings attached to, citizenship as a lived identity.

What is often missing from contemporary articulations of citizenship is the reality that there are multiple citizenships - in terms of status, experience and understanding. As we have already indicated, questions of gender serve to trouble - to call into question and complicate - definitions and conceptualisations of citizenship as a universal and unitary status. As feminist theorists have argued, citizenship theory and status generally fail to recognise difference, and do so in the name of an ideal of a universal citizen, which in fact bears the impress of a partial (masculine) notion of the abstract, undifferentiated citizen. We would argue that it is impossible to separate social identity and citizenship from their gendered contexts. This challenge of difference and the 'troubling' of citizenship can generate various responses. For example, one response is to keep a totalising and universal conception of citizenship identity, but provide special sets of rights and entitlements in order to enable disadvantaged groups to access and participate in this status. This redresses, though not necessarily addresses, difference. A more radical response is to break with any notion of a single, unified and unifying citizenship. This translates into considerations of plural notions of citizenship, a disaggregation and redefining of the elements and meanings of citizenship, and fits with understandings of social identities and citizenships as themselves plural and emerging. This also recognises citizenship as a process rather than simply a status or outcome - and understands that citizenships are negotiated, (re)produced and articulated. This reformulation has implications in terms of 
young people and transitions to citizenship(s), not least in recognising the ways in which transitions to different and diverse adult identities can skew young people's experience of and even access to citizenship, in any or all of its guises. This helps bring into relief the important distinction between the normative and material dimensions of citizenship and the need to recognise and stress the 'differential nature of citizenship experiences' (Harrison, 1991: 210). This is explored in the next section of the article, in relation to empirical work on young people's transitions to and journeys within citizenship. In particular, we draw on ethnographic data generated with young people in youth work settings to explore these relationships between gender, citizenship and emergent adult identities.

\section{Youth work and gender: three models of citizenship}

In this section we aim to ground and extend the previous discussion by drawing on some concrete observations of sites for the learning and negotiation of social identities and citizenships, and young people's experiences within these. In particular, our observations draw attention to the gendered understandings and realities which structure these experiences. The project on which this section draws has been reported elsewhere, and it is not our intention to report research 'findings' in detail (see Hall et al., 1998, 1999, 2000). We do, however, illustrate our arguments with reference to data exemplars from that wider project.

Our comments here are structured in dialogue with the models of citizenship emerging from the UK ESRC Youth, Citizenship and Social Change Programme. In reporting on a study of how young people in a British city perceive citizenship, Lister and her colleagues identify different models, five in all, in terms of which young people might identify themselves and act as citizens (see Lister et al., 2003). The five models are 'universal status', 'respectable economic independence', 'constructive social participation', 'social contractual', and 'right to a voice'. Lister reports the first three of these as the most frequently articulated by the young people in her study and it is on these three we focus here. Universal status refers loosely to ideas of social membership; respectable economic independence links the importance of waged employment and family responsibilities to citizenship; and constructive social participation 'denotes a constructive stance towards the community' (Lister et al., 2003: 238). Cross-cutting these models, Lister's respondents are reported as either 'insiders' or 'outsiders' - a proxy for social class - which then allows for a discussion of differential commitment to each of the different models of citizenship. We too aim at a discussion of the differentials in 'fit' to models of citizenship, but our principal concern here is in relation to gender. We are interested in how citizenship might mean different things for young men and young women moving into social majority and adult 'citizenship' (regardless, at least in this article, of what the term itself might mean to them).

\section{CAMBRIDGE JOURNALS}




\section{Spaces for universal citizenship}

A spatial metaphor links citizenship, youth and youth work, and allows us to recognise some of the gendered particularities of identity and citizenship in youth work settings. The assertion of emergent adult identities finds expression in the idea of space (something recognised in the recent Green Paper Youth Matters, with its ambition to increase 'things to do and places to go' for young people). Youth is, at many different levels, an expansive moment, and young people moving toward social majority will invariably feel the need for space, for room: freedom from the support and confines of those contexts that define dependency; space in which to nurture and explore their emergent sense of self. Similarly, citizenship, as a universal status, is associated with the movement into, occupancy of, and activity in, certain kinds of space, notably public space. The distinction between space and place is worth pursuing here. If citizenship as universal status has an abstract quality as set against the particularities of persons, then this is akin to the abstract quality of space as set against the particularities of place (see Augé, 1995: 82). As we have argued elsewhere (Hall et al., 1999), youth work settings have consistently sought to provide space for young people in this more abstract senseakin to citizenship - although necessarily in physical locations. Youth work settings have conventionally aimed at providing free and shared space in which young people can associate as equals on a voluntary basis. As such they are places made spaces. The ambition is to make space: for activity, involvement and society. The connection to a citizenship agenda should be apparent. Yet within many sites for youth work intended as spaces for free association for young people, it is striking just how divided the space can be - how particularities persists and 'place' people. Gender is just one such particularity.

'The Roost' is a drop-in and social club for local young people in a south Wales valleys town, offering space for leisure, activities and association on weekday evenings with light-touch adult supervision from youth workers and volunteers; it operates from first-floor premises reached by stairs from the street.

Calling in tonight, we pass a group of young men at the very foot of the stairs, stood musing whether to go in or to 'go out' instead. On the landing upstairs, two girls are smoking together and talking in urgent whispers - smoking is forbidden beyond this point; past these two and through the main door we enter the central space of the project, a large room laid out for leisure: in the near corner a television and chairs, across the room a pool table and table-tennis table, and in the far corner two sofas and more chairs casually arranged to promote sociability; other facilities, available in adjoining rooms, include a kitchen area, a meeting room and a weights and training area - a group of boys in their early teens are noisily lobbying for entry to the latter, but are told no, not tonight.

In the meeting room a slide show about an overseas aid trip - something the youth work team are keen to recruit to - is coming to an end; the audience disperses - boys for the pool table, girls for the television. On the sofas a worker and volunteer are in close conversation with a mixed group in their late teens, all of whom attended the funeral, earlier today, of a friend (and regular at 'The Roost') who died three weeks ago in a drugs-related accident. Their mood is sombre; the talk is of the events of the day and memories of the deceased. The young men 
from downstairs come up only to announce that they are off out to mark the death of their friend in their own way; two more get up from the sofas join them. 'Go easy on it tonight, boys', says the youth worker. Those remaining, all young women, drift over to the television, where a soap-opera wedding is in progress. The picture is fuzzy and there is much argument about where best to set the portable aerial, mixed in with which a running, comic and ribald commentary on the wedding itself, the suitability of the match and the attire of the guests. All the while, the youth workers and volunteers circulate - listening, scolding, joking, arbitrating; the stereo is too loud and must be turned down, the unruly queue of boys at the pool table needs organising, the surfaces in the kitchen need wiping.

This short descriptive note gives a flavour (we hope) of the richness of youth work settings as sites for the negotiation of adult identities and for the sociological investigation of such identity work. Our principal reason for including it here, however, is to serve as an indicative example - no more than this - of the persistent demarcation of gender, in activities and space, in such settings. Youth work settings make open and democratic - non-exclusionary - space for young people, but they remain pronouncedly gendered settings, in ways that necessarily cross-cut the citizenship agenda to which youth work is also always addressed. To some degree, all of the sites we visited as part of our research created or made available space for activities and association which was then occupied and used in ways that segregated - space (and activities) for boys, and space (and activities) for girls: the boys 'knock-around' football outside the club; the all-girl gathering inside, watching the domestic dramas of TV chat shows unfold; the youth council organised through a female peer-group; the 'boys' holiday/'educational' trip abroad. None of these activities is inevitably gendered, but in practice the distinctions were clearly demarcated. Some of this segregation was intended, the result of an explicitly gendered organisation of space and activity on the part of youth work staff looking to make room for emergent, gendered identities and groupings. More often, however, space occupied and activities engaged in 'just ended up', and not altogether unsurprisingly, structured in this way.

Such gender segregation did not necessarily surprise us (although questions might be asked of the more stereotypical spaces and activities so explicitly a part of the provision in some of the settings we visited). Nevertheless, in so far as youth work settings can be said to aim to make space for young people in ways which are commensurate with citizenship - spaces of voluntary association - this ambition is complicated, by the prevalence and persistence of gendered use of space. This is not to say that these settings cannot also create spaces for young men and young women to be together: they do just that, and indeed this forms a good part of their attraction for many of the young people who use them. But again, and again unsurprisingly, they do so in ways which do not dissolve difference. Gender identities and (predominantly heterosexual) gender relations were a recurrent and explicit topic of interested conversation time and again in the sites we visited - looking through magazines, talking through the events of 
the previous evening, gossiping about those not present - and were the subtext to a good many more conversations besides; they were also a staple component of the 'soft' schooling curriculum of youth work discussion groups and 'sex-ed' sessions. And what was at stake in these conversations was difference: this was where the interest lay.

We also want to note here a relationship between public space, young people and the policing of citizenship and gender identities. Public space is a domain of (universal) citizenship and yet the relationship between public space and youth work settings as an alternative to public space is a problematic one. It is a longstanding observation of youth work provision that in providing safe and supervised space for young people, it can also inadvertently de-legitimate young people's (unsupervised) occupancy of public space - as citizens perhaps. In this way, at the same time as it makes space for young people, youth work operates to police and contain their energies and prescribe activities (White, 1990). The perceived imperative to give young people 'a place to go' and space in which to do 'something constructive' - getting them 'off the streets' and out of trouble was a rationale we encountered recurrently in discussing the development of site-based projects with youth workers, many of whom were only too well aware of the contradictions in this rationale. But our point is not only that, as an 'accommodation', sites for youth work can be awkwardly situated between an appreciation of the space needs of young people and contrasting mechanisms of 'soft' policing and social control. Although the youth work settings in which we spent time were not public spaces, public space and what it meant to occupy it what it meant to be out and about and 'known' locally - was something in which the young people were very interested and sometimes anxious about.

One of the daily staples of conversation in such settings was behaviour 'outside' and in public, and the reputations consequent upon this. Here activities were being policed and declared legitimate or otherwise in discussions organised around gender identities, with the policing accomplished by young people themselves. With citizenship in mind, what was striking about these conversations who had been seen with whom and where, doing what, in public - was the stereotyped distinction, confirmed and cemented, between young men's legitimate 'active' occupancy of public space - out and about, in and out of trouble, occupying territory, knowing and becoming known around town and young women's occupancy of such space constructed as 'passive' and less legitimate altogether. The young women we got to know in some of the settings we spent time in had little or no interest in developing public reputations, in being known around town; indeed, they had an interest in avoiding such public reputations, and this was something they themselves policed, through gossip, teasing, insult and allegation. This gendered difference in the meanings attached to occupancy of public space and the public reputations that might result from such occupancy resonates, at the level of theory, with the feminist criticism of 
'universal' citizenship - abstract, undifferentiated - as implicitly masculine in its assumptions.

It is worth noting that the policing of gendered behaviour by young people themselves, at least in its more blatant and unpleasant expressions, was something most of the youth workers we knew would routinely resist and challenge. But this seldom amounted to a policy of challenging or exploring traditional gender identities. Indeed, conventional gender identities sometimes found confirmation in conversations between youth workers and young people, as we discuss in the following section.

\section{Work, family and independent citizenship}

Young people's move into adulthood and social majority takes place on a number of levels, consistently informed by gender (among other sociologically relevant differentiations) and perhaps never more so than in the case of transitions in relation to work and family life. Yet it remains unclear whether the sorts of competencies for citizenship and the kinds of citizenship identity that drive current enthusiasms match up to the aspirations, realities and identities at stake in the 'making' of young people. It is certainly the case that citizenship 'skills' and 'identities' will resonate more strongly with some young people than with others; and it seems reasonable to suggest that this mismatch is unlikely to be random, but instead will show some social patterning, and that gender is likely to be one such pattern. Consider this, from one of Lister's respondents, a 16-year-old male, elaborating on the model of citizenship as respectable economic independence: 'I think as soon as you're living in your own house, out working, paying your bills. That's when you're a citizen' (Lister et al., 2003: 238). Another of the same age and gender suggests that citizenship of this sort will come 'when I've got a house, wife, kids, job going on' (Lister et al., 2003: 238). Young men, we are told, were more likely to invoke this model. And it is easy to see why - at least couched in such traditional and gendered language. This is the citizen as (male) breadwinner; and given what we know about labour market opportunities and family responsibilities and gender, we can see why consideration of gender should immediately trouble any such notion of citizenship.

The young people with whom we spent time in our own research were not yet, any of them, firmly established in labour market positions or families of destination, but many were well on the way to being so, or were already encountering difficulties related to these aspects of transition. We want to draw attention here to the ways in which the settings we observed served as sites for the anticipation and working through of such transitions and difficulties. We have in mind a particular fieldwork site, a daytime advice and drop-in centre in a south Wales town in an area of economic hardship, ranking high on indicators of social exclusion. The young people making use of this setting as a place in which to spend time and avail themselves of the guidance and support of youth work staff, would figure as 
'outsiders' in Lister's schema. Most were already set on transition trajectories likely to limit their citizenship modelled as 'respectable economic independence'. But within these shared limitations were particular, striking and often stereotypical, differences of gender, suggestive of further limitations and constrictions.

The advice centre served as a job shop of sorts, with local employment opportunities posted on the walls. Youth workers and volunteers were always trying to draw these to the attention of young people, encouraging them to apply to this or that vacancy - and to apply themselves, more generally, to the business of thinking ahead, and positively, about adult working lives. Yet for some of those young people in regular attendance, these futures were already foreclosing. A significant minority of the young men using the project had burgeoning criminal and prison records. This experience was shared, through conversation and tacit acknowledgement, in ways which constructed a familiar solidarity, with its own consolations, which set itself, if anything, against a notion of respectable economic citizenship (see Wallace, 1987; McAra, 2005). These young men's inward adjustment of subjective aspirations to objective probabilities was something workers at the project continually strove, with limited apparent success, to open up to other possibilities. Here particular adult, male identities and probabilities were being settled on, for the time being at least, away from and in opposition to the idea of citizenship as respectable, waged, economic independence. Respectable waged work, such as was available to young people locally, did not want these young people; and these young people, in turn, were finding ways in which to reconcile themselves to this, together, as young men. (Very few of the young women attending the project, by contrast, had criminal records; none had any direct experience of prison life.)

This particular, gendered expression of inequality and labour market opportunity is a familiar one, as were the work opportunities for those young people using the project whose prospects were brighter: young people aiming towards training, and applying for jobs - as hairdressers, beauticians, pipe fitters, motor mechanics and secretaries. These working futures were anticipated by young people in familiarly gender-stereotyped fashion.

Emma, aged seventeen and a regular visitor to the centre, calls for coffee and a chat. She spends a little time looking through the jobs on the wall, and is encouraged to do so by the youth worker on duty. A lot of the ads, it turns out, require experience (she has none) and someone a little older, ideally. Emma has very few school qualifications and dropped out of college a few weeks ago by more or less mutual agreement, following a lengthy period of poor attendance. One vacancy is a possibility at least: an assistant in an old people's home, experience 'would be an advantage' but is not required. Emma is not fired up about this though. She doesn't know if she could bring herself to do that sort of work, 'cleaning up after incontinent old people'. She drifts away from the jobs board and settles on the sofa with a newspaper and a cup of coffee. Turning the pages she explains that she has been 'sort of offered' a modelling job with one of the local ladies' outfitters that advertises in the local paper. She would get $\mathfrak{2}_{20}$ cash for appearing in the ad and would be allowed to keep some of the clothes, which she feels is a good deal. 
At a first and casual glance, the difference between these two working 'futures' care assistant and model - might seem significant, but what is of course fundamentally significant is the similarity between two stereotypically gendered work opportunities in a given class context (see Gaskell, 1991; Skeggs, 1997; Osler and Vincent, 2003). We could add that both jobs are part-time: the first, two days a week, the second cash in hand and payment in kind for a few hours work at most, neither job would pay a living, still less a family wage.

A further, final (and again familiar) trajectory in evidence at this particular project, one that bears on the theme of citizenship as economic and family responsibility, was parenthood. A number of teenage mums-to-be made use of the project during the time we spent there and for these young women, soon to be parents and with at best tenuous prospects of support from their erstwhile partners, citizenship of the sort indicated by the two respondents to Lister's study was receding as fast as it was gained. Parenthood was likely to bring (adult) responsibilities and a recognised route and enfranchisement into social majority, but also difficulties and quite possibly exclusions - from work and, certainly for the single mothers we knew during fieldwork, even exclusion from the proxy citizenship implied by citizenship models of the waged and working 'breadwinner' (see Chevalier and Viitanen, 2003).

We want to emphasise that the transitions we have discussed here were not only undergone by some of the young people we have mentioned in ways which were visible to us through attending youth work settings, but were actively worked at there. That is, these were transitions that (some) young people brought to youth work projects as aspects of their lives with which they wanted help. In the same way, the youth workers on duty saw these life decisions and challenges as precisely the legitimate object of their professional intervention - matters on which they could offer practical advice and support. As is the way with youth work practice, such advice and support was not always directly offered in the form of overt tuition or mentoring so much as conveyed within the context of informal and leisure activities, in casual conversation and indirectly. Such strategies for informal education - advice given off rather than given out, lessons caught rather than taught - are constitutive of youth work. Such tacit education can operate particularly powerfully when lessons are being learned about social identity, and we were struck by this throughout our fieldwork.

The project is busy all morning with a continuous traffic of young people: the front door bangs open and closed; the sofa fills up, empties and fills up again; the kettle never cools. Some callers bring particular problems - personal, bureaucratic, financial - for which they want advice, information, or permission to use the phone or computer; some just want five minutes and a sympathetic ear. Others drop in simply to say hello and spend time. Emma, Sarah and Carol are around for most of the morning, as usual, passing time. Julie calls in at midday. She has been away from her mother's since yesterday afternoon and, having spent last night out, knows that she will be in big trouble when she gets home. Eddie [youth worker] tries to persuade Julie 
to give her mother a call on the phone, but Julie is reluctant. Emma and Sarah, sat on the sofa with coffees and cigarettes, take an interest and start to scold Julie, telling her she will get herself a reputation 'hanging about and going into boys' bed-sits and that'. Eddie intervenes, but Julie is already upset and doesn't stay. Matt arrives, with girlfriend Rachel in tow; he is pestering her for kisses, insisting that he 'can't help' himself after 'six weeks without it' - a laboured allusion to his recent release from prison. Rachel is as pleased with the attention as Matt is with himself; even so, she pushes him away every now and then, telling him to 'get off.

The project fills to capacity in the early afternoon as the lunch-time crowd from the FE college call in, then quickly empties. The rest of the day is quiet, and passes slowly. In the office, Eddie works away with Debs [youth worker] on an application for project funding. Jane and Ruby [volunteers] tidy the main room and sit chatting with the afternoon's only callers: Penny and Maria. Both girls - Penny and Maria, each 17 years old - are heavily pregnant, and have called by just to get out of the weather and have a sit down. The conversation is casual but supportive, mixing sensible advice and offers of practical assistance with jokes and personal anecdotes about pregnancy, childbirth and motherhood. Much of the humour is directed at men - men in general and boyfriends/husbands in particular; Jane and Ruby do not hold back. The scene is in conspicuous symmetry to that of yesterday afternoon, when Martin and Scott were here for an hour between college classes, and were sat drinking tea with Eddie and Chris [volunteer]. On that occasion the talk was all of workplace hi-jinks and crudely comic stories from Eddie's days in the army. Martin and Scott were as avid listeners then - laughing along, and asking to hear more - as Penny and Maria are today.

At the project we have referred to throughout this section, the youth workers and volunteers were mostly local residents, many of them with personal experience, in their youth, of similar issues to those faced by young people making use of the centre-unemployment and early motherhood, for example. This afforded them a crucial credibility; the advice and support they offered were all the more plausible because grounded in the familiar, and couched in a language of local experience. Yet local experience and the idioms through which it could be familiarly spoken were nothing if not gendered. In this way the most casual of conversations about past experience or local affairs, à propos of nothing, could be an education whether intended as such or not: factory floor pranks recalled; fond recollections of young motherhood and jokes, in this context, about useless partners; army life and travel remembered. Seemingly casual conversations of this kind could hold the young people as audience better than any 'formal' employment advice workshop or parenting skills session, replete as they so often were with glimpses of possible futures, adult identities and experiences through which to view one's own burgeoning adulthood, and with the occasional enfranchisement - invariably through humour - into the sense and idioms of the local adult world.

As observers and occasional participants to these conversations we were invariably struck by the extent to which these glimpses, identities, experiences and enfranchisements were structured by traditional gender divisions. This was to be expected of conversations that reported on and were the product of a setting in which such gender divisions operated daily as part of the fabric of community life, which is precisely why the young people using the centre valued them - here 
they could learn about being, by hearing from, local men and women. Models of citizenship organised around the idea of respectable economic independence are inevitably complicated by such learning, because revealed as so powerfully gender differentiated.

\section{Participation for citizenship}

As we expected, our research generated substantial data on participation, volunteering and community involvement. Such activities are often the breadand-butter of youth work and other informal educative settings and certainly the most visible. It is in this respect that youth work really goes public with an active citizenship agenda, encouraging and enabling positive engagement on the part of young people in the community in the open, as it were, where young people's efforts can be recognised and their citizenship - as contributors to the public life of the community - assured. Many of the community activities and engagements we observed were, as it turned out, sex-segregated, though by no means all. But this generally resulted from young people's propensity to use existing gender peer groups as the basis for organising themselves in response to opportunities provided through youth work settings (and despite the sometimes concerted attempts of youth workers to unravel these groupings and create more genderbalanced groups). We would hesitate to make any gender claims about respective enthusiasm for, or the practice of, participation among young men and young women, notwithstanding the comments we have made already about the ways in which youth work settings can and do serve as sites for the (re)production of gender identities. However, it does seem to us that gender is very profoundly, because tacitly, a part of the universal calls to good citizenship through active engagement.

Whether or not the particular public activity in question can be considered a 'boys' thing' or a 'girls' thing', and even where the young people participating are gender-mixed, the very notion of public participation as citizenship rests on and confirms a profound gender differentiation. Citizenship understood as active citizenship and public works invites and requires another realm and mode against which to define itself: the private and passive. Either that or it sets its own creativity and contribution - public, social - against other creativities - family, children. The asymmetric power relations that such binary symbolisations have secured have always turned on gendered difference, in ways which have implied citizenship, as domain and activity, as constitutively male (and continue to do so, notwithstanding changes to labour market and family structures). Encouraging young people to participate in public, community and educative endeavours representing the local youth constituency through a young people's council, collecting money for local charities, participating in an overland aid trip to Croatia - do not significantly challenge such notions of citizenship and could even be said to affirm the very dichotomies that have historically constructed 
women as second-class citizens. It is worth noting here that that much of the current negative and anxious commentary about young people and the 'don't care' culture is implicitly, and sometimes explicitly, directed at young men in particular. To the extent that the problem is constructed as one of young men not contributing to their communities (as active citizens), young women and their contributions and citizenship are sidelined, assumed to be unproblematic or not considered at all.

\section{Concluding comments}

Citizenship, and all that it can be made to mean and imply, figures across a range of contemporary public and policy concerns; it is very much a part of today's political vocabulary, where it figures as a language of both anxiety and aspiration. It is also, and for this very reason, a concept, worthy of close, critical attention. In this article we have paid particular attention to (anxieties about and aspirations for) youth and citizenship, and have focused on the 'learning' of identities and citizenship in the context of young people's transitions to adulthood and social majority. In doing so, we have asked questions of citizenship - as activity, as practical competency, as social identity - and gender. We have suggested that contemporary models of youth and citizenship do not always take into consideration the gendered contexts and experiences of young people's move to social majority. Taking three models of citizenship extrapolated from citizenship research with young people (see Lister et al., 2003) we have discussed each in turn, reflecting on our own experiences in youth transitions research in youth work settings (which themselves have a long-standing, if diffuse, citizenship agenda or curriculum). We have argued elsewhere (Hall et al., 1999, 2000) that youth work settings provide a particularly productive site in which to investigate the negotiation, exploration and learning in which young people engage as they move towards identities for future adulthoods and citizenships. There is no mistaking the present affinity between many of the statements of intent and aspiration in the DfES Green Paper, Youth Matters, and those that have long informed youth work practice: claims of, for and about citizenship.

Questions of gender segregation, explored empirically and theoretically, form a significant component of a wider sociology of education (see Francis and Skelton, 2001; Arnot and Mac an Ghaill, 2005), but are not so often brought directly to bear on the learning of citizenship; similarly, youth work settings are not always recognised as significant sites of (informal) education. Here we have drawn attention to youth work settings as sites in and through which gender identities are not only negotiated, but inevitably mediate other aspects of identity work and informal learning (as much as anywhere else - at home, at school, outdoors). This has allowed us to consider, through a gender lens, the intersection of youth work provision and aspects of a citizenship-educative 
agenda. In bringing these two together we hope we have been able to raise wider questions: of education for citizenship and of citizenship itself as experienced by young people.

\section{Note}

1 We acknowledge the support of the Economic and Social Research Council (Rooo236673) in funding this research project.

2 Seehttp://www.gnn.gov.uk/content/detail.asp?NewsAreaID=2\&ReleaseID $=173518$ (accessed 2 March 2006)

\section{References}

Arnot, M. and Mac an Ghaill, M. (eds) (2005), The RoutledgeFalmer Reader in Gender and Education, London: RoutledgeFalmer.

Augé, M. (1995), Non-Places: Introduction to an Anthropology of Supermodernity, London: Verso. Butler, J. (1990), Gender Trouble, London: Routledge.

Chevalier, A. and Viitanen, T. (2003), 'The long run labour market consequences of teenage motherhood', Journal of Population Economics, 16: 2, 323-343.

Chisholm, L. (1997), 'Social citizenship, Europe and young people', Paper presented at the Séminaire Citoyenneté des Jeunes en Europe, Marly-le-Roi, January/February.

Coles, B. (1995), Youth and Social Policy: Youth Citizenship and Young Careers, London: UCL Press.

Cunningham, S. and Lavalette, M. (2004), “Active citizens" or "irresponsible truants"? School Student Strikes against the War', Critical Social Policy, 24: 2, 255-269.

DfES (2005), Youth Matters, Cm 6629, Norwich: The Stationery Office.

Fergusson, R. (2004), 'Discourses of exclusion: reconceptualising participation among young people', Journal of Social Policy, 33: 2, 289-320.

France, A. (1996), 'Youth and citizenship in the 199os', Youth and Policy, 53, 28-43.

France, A. (1998), “"Why should we care?": young people, citizenship and questions of social responsibility' Journal of Youth Studies, 1: 1, 97-111.

Francis B. and Skelton C. (eds) (2001), Investigating Gender: Contemporary Perspectives in Education, Buckingham: Open University Press.

Gaskell, J. (1991), Gender Matters from School to Work, Milton Keynes: Open University Press.

Hall, T. and Williamson, H. (1999), Citizenship and Community, Leicester: Youth Work Press.

Hall, T., Coffey, A. and Williamson, H. (1999), 'Self, space and place: youth identities and citizenship', British Journal of Sociology of Education, 20: 4, 501-513.

Hall, T., Williamson, H. and Coffey, A. (1998), 'Conceptualizing citizenship: young people and the transition to adulthood', Journal of Education Policy, 13: 3, 301-315.

Hall, T., Williamson, H. and Coffey, A. (2000), 'Young people, citizenship and the third way: a role for the youth service?', Journal of Youth Studies, 3: 4, 461-472.

Harrison, M. L. (1991), 'Citizenship, consumption and rights: a comment on B. S. Turner's theory of citizenship', Sociology, 25: 2, 209-213.

Jenkins, R. (2004), Social Identity, 2nd edition, London: Routledge.

Jones, G. and Wallace, C. (1992), Youth, Family and Citizenship, Buckingham: Open University Press.

Lister, R. (2003), Citizenship: Feminist Perspectives, Basingstoke: Palgrave Macmillan.

Lister, R., Smith, N., Middleton, S. and Cox, L. (2003), 'Young people talk about citizenship: empirical perspectives on theoretical and political debates', Citizenship Studies, 7: 2, 235253.

Mac an Ghaill, M. (1994), The Making of Men, Buckingham: Open University Press.

MacDonald, R. (1997), 'Dangerous youth and the dangerous class', in R. MacDonald (ed.), Youth, the 'Underclass' and Social Exclusion, London: Routledge.

\section{CAMBRIDGE JDURNALS}


Macdonald, R. and Marsh, J. (2004), 'Missing school: educational engagement, youth transitions, and social exclusion', Youth and Society, 36: 2, 143-162.

McAra, L. (2005), 'Gender, youth transitions and crime', British Society ofCriminology E-Journal, 6: 5, http://www.britsoccrim.org/volume6/o05.pdf.

National Assembly for Wales (2001), The Learning Country, Cardiff: National Assembly for Wales.

Osler, A. and Vincent, K. (2003), Girls and Exclusion, London: RoutledgeFalmer.

Proweller, A. (1998), Constructing Female Identities, Albany NY: State University of New York Press.

QCA (1998), Education for Citizenship and the Teaching of Democracy in Schools: Final Report of the Advisory Group on Citizenship, London: Qualifications and Curriculum Authority.

Renold, E. (2005), Girls, Boys and Junior Sexualities, London: RoutledgeFalmer.

Russell, I. M. (2005), A National Framework for Youth Action and Engagement: Report of the Russell Commission, Norwich: HMSO.

Skeggs, B. (1997), Formations of Class and Gender, London: Sage.

Walkerdine, V., Lucey, H. and Melody, J. (2001), Growing Up Girl, London: Palgrave Macmillan.

Weis, L. and Fine, M. (2000), 'Disappearing acts: a feminist dystopia for the 2oth century', Signs, 25: 1139-1148.

Wallace, C. (1987), For Richer for Poorer, London: Tavistock.

White, R. (1990), No Space of their Own, Cambridge: Cambridge University Press.

\section{CAMBridge JDURNALS}

